\title{
Flank instability assessment at Kick-'em-Jenny submarine volcano (Grenada, Lesser Antilles): a multidisciplinary approach using experiments and modeling
}

\author{
F. J-Y. Dondin ${ }^{1}$ - M. J. Heap ${ }^{2}$ - R. E. A. Robertson ${ }^{1}$ - J-F. M. Dorville ${ }^{3} \cdot$ S. Carey $^{4}$
}

Received: 27 May 2016/Accepted: 6 December 2016/Published online: 20 December 2016

(C) The Author(s) 2016. This article is published with open access at Springerlink.com

\begin{abstract}
Kick-'em-Jenny (KeJ) - located ca. 8 km north of the island of Grenada - is the only active submarine volcano of the Lesser Antilles Volcanic Arc. Previous investigations of $\mathrm{KeJ}$ revealed that it lies within a collapse scar inherited from a past flank instability episode. To assess the likelihood of future collapse, we employ here a combined laboratory and modeling approach. Lavas collected using a remotely operated vehicle (ROV) provided samples to perform the first rock physical property measurements for the materials comprising the KeJ edifice. Uniaxial and triaxial deformation experiments showed that the dominant failure mode within the edifice host rock is brittle. Edifice fractures (such as those at Champagne Vent) will therefore assist the outgassing of the nearby magma-filled conduit, favoring effusive behavior. These laboratory data were then used as input parameters in models of slope stability. First, relative slope stability analysis revealed that the SW to N sector of the volcano displays a deficit of mass/volume with respect to a volcanoid (ideal 3D surface). Slope stability analysis using a limit equilibrium method (LEM) showed that $\mathrm{KeJ}$ is currently stable, since all values of stability factor or factor of safety (Fs) are greater than unity.
\end{abstract}

Editorial responsibility: J. Dufek

F. J-Y. Dondin

fredericdondin@gmail.com

1 Seismic Research Centre, The University of the West Indies, Gordon Street, St Augustine, Trinidad and Tobago

2 Géophysique Expérimentale, IPGS, UMR 7516 CNRS, Université de Strasbourg/EOST, Strasbourg, France

3 MF-DIRAG Météo France Direction Inter-Régionale Antilles Guyane, Fort-de-France cedex, Martinique, France

4 Graduate School of Oceanography, University of Rhode Island, Narragansett, RI, USA
The lowest values of Fs were found for the SW-NW sector of the volcano (the sector displaying a mass/volume deficit). Although currently stable, KeJ may become unstable in the future. Instability (severe reductions in Fs) could result, for example, from overpressurization due to the growth of a cryptodome. Our modeling has shown that instabilityinduced flank collapse will most likely initiate from the SWNW sector of KeJ, therefore mobilizing a volume of at least ca. $0.7 \mathrm{~km}^{3}$. The mobilization of ca. $0.7 \mathrm{~km}^{3}$ of material is certainly capable of generating a tsunami that poses a significant hazard to the southern islands of the West Indies.

Keywords Volcanic landslide - Limit equilibrium method · Flank collapse-generated tsunami $\cdot$ Seamount

\section{Introduction}

Volcano slope instability is the prerequisite condition for volcano flank collapse and their potentially devastating consequences (McGuire 1996). Slope instability in volcanic environments is far more complex than in nonvolcanic environments (Voight and Elsworth 1997; Apuani and Corazzato 2009). Morphological, geologic, tectonic, and climatic factors, as well as shallow magmatic injection, hydrothermal activity, and volcano-tectonic factors are recognized as destabilizing mechanisms at volcanoes (e.g., Voight et al. 1983; McGuire 1996; van Wyk de Vries and Francis 1997; Voight and Elsworth 1997; Reid et al. 2001; van Wyk de Vries and Delcamp 2016). The consequences of flank instability are often devastating and deadly (McGuire 1996; Auker et al. 2012). An additional hazard provided by volcanic edifices located under or proximal to large water bodies is the generation of highly hazardous tsunamis (e.g., Ward and Day 2001; Nishimura 2008). 
The volcanic islands of the Lesser Antilles Volcanic Arc display evidence of recurrent phases of slope instability, highlighted by horseshoe-shape structures inland and debris-avalanche deposits identified both inland and underwater. At least 52 episodes of flank collapse have been identified in the arc so far (e.g., Friant et al. 2015; Boudon et al. 1984, 1987, 2007; Brunet et al. 2016; Crutchley et al. 2013; Deplus et al. 2001; Dondin et al. 2012; Karstens et al. 2013; Komorowski et al. 2005; Lindsay and Shepherd 2005; Lebas et al. 2011; Legendre 2012; Le Friant et al. 2002; 2003, 2004, 2009; Trofimovs et al. 2013; Voight et al. 2002; Watt et al. 2012a, b). While evidence of past volcanic landslide-generated tsunamis in the Lesser Antilles Arc is yet to be found, some past flank collapse events had the potential to generate hazardous tsunamis (Dondin 2010; Watt et al. 2012a; Friant et al. 2015; Brunet et al. 2016). Physical modeling of tsunamis generated using a pneumatic landslide tsunami generator, capable of generating landslides with varying geometry and kinematics, should improve our understanding of these complex phenomena, improve our ability to identify past events, and allow for an initial rapid tsunami assessment (McFall and Fritz 2016). Though of nonvolcanic origin, the last deadly landslidegenerated tsunami in the Caribbean was generated as a consequence of the 12 January 2010 magnitude $M_{\mathrm{w}}=7.0$ Haiti earthquake. This tsunami took place in the Gulf of Gonave and it killed at least three people at Petit Paradis inside the Gulf of Gonâve as a result of poor tsunami awareness (Fritz et al. 2013).

Kick-'em-Jenny (KeJ) (Fig. 1), the only active submarine volcano of the Lesser Antilles Arc, is located ca. $8 \mathrm{~km}$ north of Grenada island (Lindsay et al. 2005). It is a richly amphibolephyric basaltic to basaltic andesite stratovolcano (Sigurdsson and Shepherd 1974; Devine and Sigurdsson 1995). KeJ's last Tphase seismic crisis occurred on 23-24 July 2015; however, any potential eruptive activity had to be inferred during this period due to the lack of constraint on the seismic information recorded at the time by a temporarily reduced monitoring network (Latchman et al. 2015). Three episodes of flank collapse

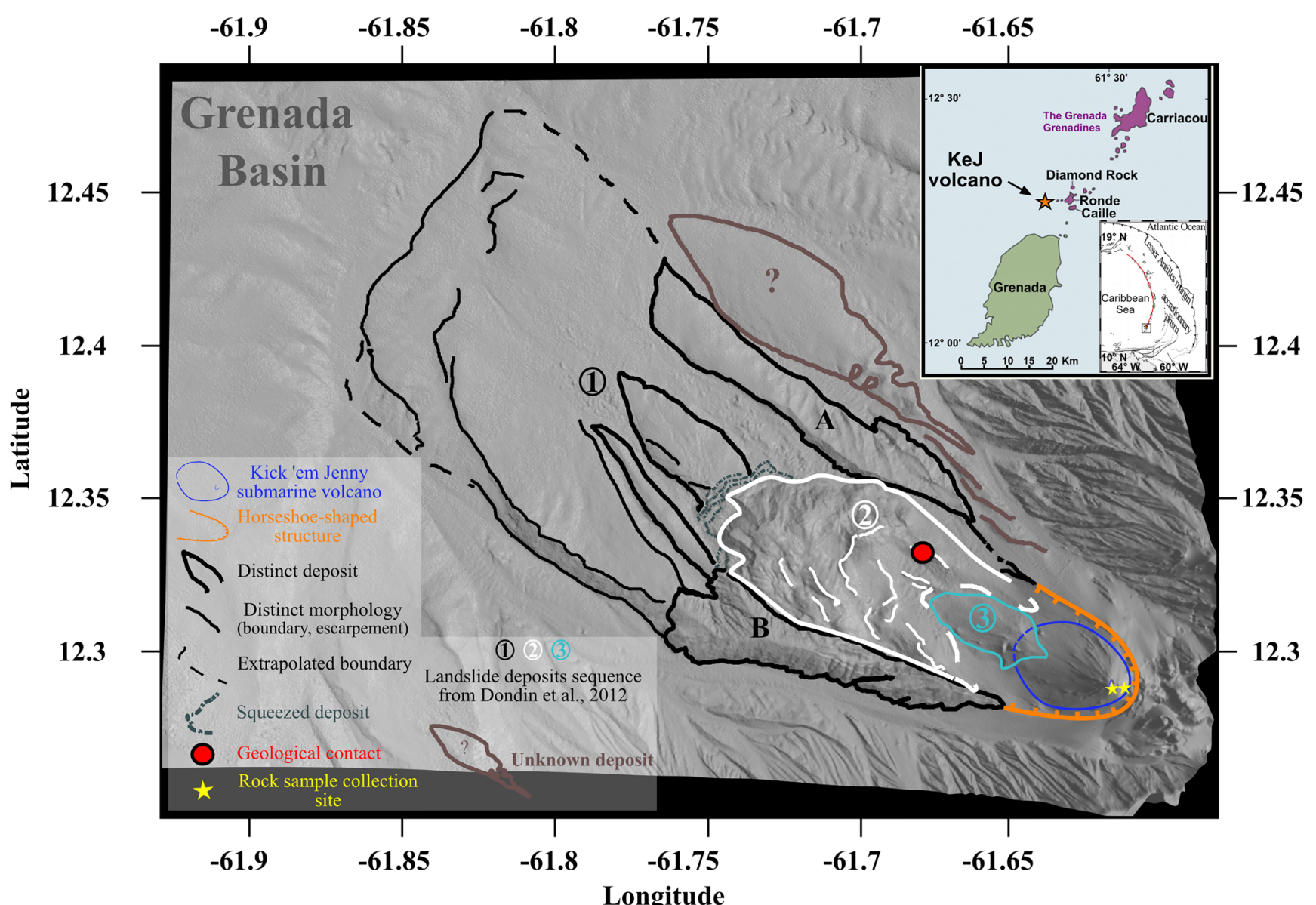

Fig. 1 Kick-'em-Jenny submarine volcano $(\mathrm{KeJ})$ and its associated submarine landslide deposits. The red dot indicates the location of a geological contact - used for radiocarbon dating to find the minimum age for landslide deposition - between the second generation landslide deposit and a layer of carbonate sediment. The labels $A$ and $B$ refer to two levees associated with the first generation of landslide deposit (1). Topright inset displays a color map of the geographical location of KeJ taken from Lindsay et al. (2005) and used with the editor's permission. Smaller inset displays a map showing the Lesser Antilles Volcanic Arc (red line). The figure is adapted from Figure 1-A in Dondin et al. (2012). The digital terrain model (DTM) is derived from multibeam data collected by a Kongsberg EM320 (32 kHz) echo-sounder mounted on E/V Nautilus during the 1-18 November 2013 NA039 Nautilus cruise 
have been identified at KeJ (Dondin et al. 2012). The second most recent flank collapse, which created a ca. $3.6 \times 3.1-\mathrm{km}$ horseshoe-shaped structure (Fig. 1), has been dated to have formed at least $43.5 \mathrm{kyr}$ BP (based on radiocarbon dating; S. Carey, personal communication). The most recent collapse event occurred within this horseshoe-shaped structure (Fig. 1). This recent collapse episode suggests that the sliding surface left by the previous landslide played the role of a weak basal layer. A similar process has been proposed for the generation of multiple landslides at other centers in the arc (see Le Friant et al. 2003; Boudon et al. 2007). The current conical-shaped edifice also lies within this structure (Boudon et al. 1999; Lindsay and Shepherd 2005; Dondin 2010; Dondin et al. 2012). Questions have been raised as to the stability of KeJ for two principal reasons. First, $\mathrm{KeJ}$ is growing on the weak basal layer left by the $43.5-\mathrm{kyr}$ BP collapse. Second, $\mathrm{KeJ}$ is located on the inclined slope (ca. $22^{\circ}$ slope) of the eastern flank of the Grenada Basin. One potential consequence of a future collapse is the generation of a tsunami that could pose a significant hazard to some of the southern islands of the West Indies (Harbitz et al. 2012; Dondin (pers. comm)).

Previous studies (Smith and Shepherd 1996; Harbitz et al. 2012) on landslide-generated tsunami hazards at KeJ are based on proposed, not calculated, values for the initial failed volume ( 0.01 and $0.6 \mathrm{~km}^{3}$, respectively). Dondin (pers. comm) presented the first study that takes into account slope stability assessment to evaluate potential collapse volumes at KeJ, the dynamics of these collapses, and the effect of the dynamics on the generation of tsunami events. These authors used a relative flank instability assessment that accounted for the morphological analysis of the current edifice and a slope stability analysis based on the work of Borselli et al. (2011). In contrast to subaerial landslide-generated tsunamis triggered by landslides with supercritical motion (e.g., Fritz et al. 2009), submarine landslide motion is subcritical with $\mathrm{Fr}<1$ (Fr, the Froude number, is the ratio of the landslide speed to the linear long-wave speed of the tsunami wave at a defined water depth; e.g., Harbitz et al. 2006).

Due to the potential danger posed by KeJ, and our limited understanding of the probability of future instability, we present here a new evaluation using a limit equilibrium method (LEM) that benefits from the first ever rock mechanics uniaxial and triaxial tests performed on materials collected from KeJ during the 1-18 November 2013 NA039 E/V Nautilus cruise (Carey et al. 2014).

\section{Materials and methods}

\section{Materials}

We provide rock physical property data for two volcanic rock samples collected during the 1-18 November 2013 NA039 E/V Nautilus cruise carried at KeJ. Both samples were collected using a remotely operated vehicle (ROV). The first sample (NA039-13) was a black, plagioclase-phyric basaltic andesite with granule fractures collected from a columnar-jointed outcrop (Fig. 2) within the crater of KeJ (12.29932 N; 61.6379 W; collection site shown on Fig. 1). The second sample (NA039056) was a gray, massive, plagioclase-phyric basaltic andesite containing bio-encrustation and a manganese crust. The second sample was collected on the wall of the horseshoe-shaped structure on which abuts the eastern flank of the KeJ edifice (12.29816 N; 61.6323 W; collection site shown on Fig. 1).

\section{Methods}

\section{Rock physical property measurements}

All measurements and deformation experiments were performed at the Laboratoire de Géophysique Expérimentale (Experimental Geophysics Laboratory) of the Institut de Physique du Globe de Strasbourg (IPGS) located at the University of Strasbourg. Cylindrical core samples of diameters 12 and $20 \mathrm{~mm}$ (with lengths ca. $30 \mathrm{~mm}$ and between ca. 30 and $40 \mathrm{~mm}$, respectively) were prepared from the blocks collected. In total, seven cores were prepared (four and three cores from samples NA039-013 and NA039-056, respectively). The cores were washed and then dried under a vacuum at $40{ }^{\circ} \mathrm{C}$ for at least $48 \mathrm{~h}$. The porosity of each core was determined using a helium pycnometer (Micromeritics AccuPyc II 1340). The P-wave velocity of each sample was measured along the axis of the cylindrical samples under ambient laboratory conditions and an axial stress of ca. $1 \mathrm{MPa}$ (using a frequency of $700 \mathrm{kHz}$ and $10 \mathrm{~V}$; see Heap et al. 2014a). Gas (nitrogen) permeability was measured on the $20 \mathrm{~mm}$-diameter samples in a benchtop steady-state gas permeameter (see Heap and Kennedy 2016) under a confining pressure, $P_{\mathrm{c}}$, of $1 \mathrm{MPa}$. Flow rates were collected under a variety of differential pressures to calculate permeability using Darcy's law and to assess the need for the Klinkenberg and/or the Forchheimer correction.

The 12-mm-diameter samples were then vacuum-saturated in distilled water and deformed in a uniaxial $\left(\sigma_{1}>\sigma_{2}=\sigma_{3}=0\right)$ compressive load frame (see Heap et al. 2014a). Samples were deformed within a distilled water bath at a constant strain rate of $10^{-5} \mathrm{~s}^{-1}$ until macroscopic failure. A load cell and a displacement transducer recorded axial load and axial displacement, respectively. These values were converted to axial stress and strain using the sample dimensions.

A sample of NA039-013 (20 mm in diameter and ca. $40 \mathrm{~mm}$ in length) was vacuum-saturated in distilled water and deformed in a triaxial $\left(\sigma_{1}>\sigma_{2}=\sigma_{3}\right)$ deformation apparatus (see Heap et al. 2014b). The triaxial test was performed under drained conditions (drainage was assured by the reasonably high permeability of sample; Table 1; see Heap and Wadsworth 2016) with a constant fluid pore pressure, 


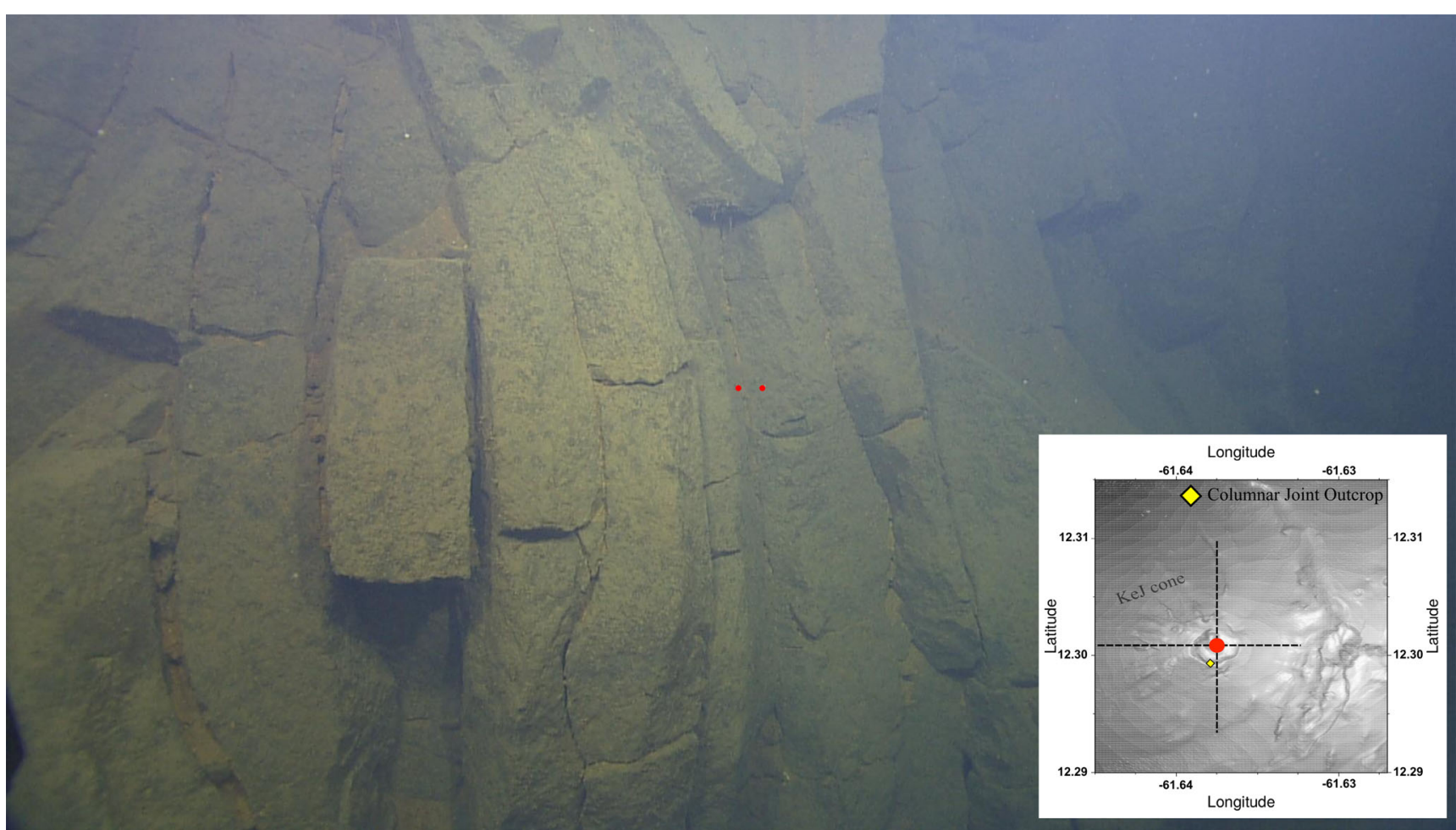

Fig. 2 Columnar-jointed rock in outcrop on the northwestern flank of $\mathrm{KeJ}$ outer crater. We infer that this deposit is related to the mid-1980s lava dome that previously filled the crater and was partially destroyed during the 1988 eruption (Shepherd 1988; Sigurdsson 1989). Rock sample

$P_{\mathrm{p}}$, of $7 \mathrm{MPa}$. This value corresponds to the pressure of the water column at the base of a vertical axis of 696 m considering that $P=\rho_{\mathrm{w}} \cdot g \cdot h$, where $\rho_{\mathrm{w}}$ is the water density, $g$ is the acceleration due to gravity, and $h$ is the water column height (Fig. 3a). We applied a $P_{\mathrm{c}}$ of $14 \mathrm{MPa}$, corresponding to the pressure at the base of a vertical axis of $696 \mathrm{~m}$ cutting through the volcano cone (Fig. 3). We assume here a simple effective pressure $\left(P_{\text {eff }}\right)$ law $P_{\text {eff }}=P_{\mathrm{c}},-\alpha P_{\mathrm{p}}$ and that poroelastic constant $\alpha$ equals $1 ; P_{\text {eff }}$ is therefore considered to be $7 \mathrm{MPa}$ for our experiment. A recent study has shown that $\alpha$ is very close to 1 for porous andesites, thus validating our assumption (Farquharson et al. 2016a). A load cell and a displacement transducer recorded axial load and axial displacement, respectively. These values were converted to axial stress and strain using the sample dimensions. All the experiments were performed at room temperature. In this study, we consider compressive stresses and strains as positive. Table 1 summarizes the data collected during the laboratory experiments.

\section{Relative instability analysis}

The approach used in this study was first proposed by Borselli et al. (2011). The approach involves comparing the results of two independent methods: (i) a morphological analysis of the volcanic edifice with (ii) results from a slope stability
NA039-013 was collected from this outcrop. The red laser dots are $10 \mathrm{~cm}$ apart. Black dashed lines in inset represent the median axis of the sectors N0-N90-N180-N270 presented in Fig. 3c

assessment to find the most unstable sector of the volcanic edifice and therefore the source of potential flank collapse.

\section{Morphological analysis}

The method of Borselli et al. (2011) consists of detecting deficit/surplus of mass/volume at a volcano by comparing a high-resolution digital terrain model (DTM) of the targeted volcano with a mathematical model (3D surface) seen as an isotropic shape without preferential direction of collapse due to intrinsic geometric nonhomogeneities. We used a $10 \times 10$ $\mathrm{m}$ lateral resolution DTM derived from multibeam data collected during the March 2003 RB03-03 NOAA cruise, and a truncated conical model to generate the 3D surface. The analysis was performed using the freeware VOLCANOFIT 2.0 (Borselli et al. 2011).

\section{Slope stability assessment by computation method}

We performed a LEM to analyze the slope stability condition of KeJ. LEMs are well-established methods to test slope stability at volcanoes (e.g., Voight et al. 1983; Iverson 1995; Elsworth and Voight 1996; Hürlimann et al. 2000; Reid et al. 2000; Donnadieu et al. 2001; Okubo 2004; Apuani and Corazzato 2010; Borselli et al. 2011), and are flexible computation methods that permit the study of external forces, seismic 
Table 1 Summary of the rock physical property measurements. Sample NA039-013-01 was used for triaxial testing; samples NA039-013-02 and NA039-05601 were used for permeability, porosity, and P-wave velocity measurement; samples NA039013-03, NA039-013-04, and NA039-056-02 were used for uniaxial compressive strength (UCS) testing

\begin{tabular}{|c|c|c|c|c|c|c|}
\hline Samples & $\begin{array}{l}\text { NA039- } \\
013-01\end{array}$ & $\begin{array}{l}\text { NA039- } \\
013-02\end{array}$ & $\begin{array}{l}\text { NA039- } \\
013-03\end{array}$ & $\begin{array}{l}\text { NA039- } \\
013-04\end{array}$ & $\begin{array}{l}\text { NA039- } \\
056-01\end{array}$ & $\begin{array}{l}\text { NA039- } \\
056-02\end{array}$ \\
\hline Length (mm) & 41.18 & 31.28 & 30.53 & 30.17 & 29.15 & 31.42 \\
\hline Diameter (mm) & 19.97 & 20.00 & 11.99 & 11.95 & 20.02 & 12.00 \\
\hline Dry mass (g) & - & 23.02 & - & - & 21.59 & - \\
\hline Wet mass (g) & - & 24.30 & - & - & 22.51 & - \\
\hline Archimedes mass (g) & - & 14.66 & - & - & 13.66 & - \\
\hline Bulk volume $\left(\mathrm{cm}^{3}\right)$ & 12.90 & 9.83 & 3.45 & 3.38 & 9.18 & 3.55 \\
\hline Dry density $\left(\mathrm{g} / \mathrm{cm}^{3}\right)$ & - & 2.34 & - & - & 2.35 & - \\
\hline Wet density $\left(\mathrm{g} / \mathrm{cm}^{3}\right)$ & - & 2.47 & - & - & 2.45 & - \\
\hline $\begin{array}{l}\text { Density-assuming } 100 \% \\
\text { water saturation }\left(\mathrm{g} / \mathrm{cm}^{3}\right)\end{array}$ & - & 2.49 & - & - & 2.47 & - \\
\hline Pycnometer volume $\left(\mathrm{cm}^{3}\right)$ & 11.25 & 8.36 & 2.97 & 2.91 & 8.07 & 3.13 \\
\hline Connected porosity (\%) & 12.76 & 14.95 & 13.92 & 13.93 & 12.09 & 11.99 \\
\hline$V p$ travel time $(\mu s)$ & 17.52 & 12.80 & 12.82 & 12.46 & 14.32 & 15.20 \\
\hline P-wave velocity $(\mathrm{km} / \mathrm{s})$ & 3.35 & 4.12 & 4.01 & 4.16 & 3.20 & 3.15 \\
\hline $\begin{array}{l}\text { Uniaxial compressive } \\
\text { strength (MPa) }\end{array}$ & - & - & 95.68 & 71.56 & - & 54.63 \\
\hline $\begin{array}{c}\text { Peak differential stress at } \\
P_{\text {eff }}=7 \mathrm{MPa}(\mathrm{MPa})\end{array}$ & 180.54 & 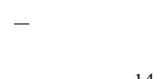 & - & - & 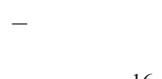 & - \\
\hline $\begin{array}{l}\text { Permeability (nitrogen) at a } \\
\text { confining pressure of } \\
1 \mathrm{MPa}\left(\mathrm{m}^{2}\right)\end{array}$ & $1.57 \times 10^{-15}$ & $1.01 \times 10^{-14}$ & - & - & $7.27 \times 10^{-16}$ & - \\
\hline
\end{tabular}

effects, shallow magma intrusions, fluid pressure, or overpressure (e.g., Iverson 1995; Donnadieu et al. 2001; Apuani et al.
2005, 2009). A LEM applied to volcano stability assumes a 2D section consisting of strata with assigned geomechanical

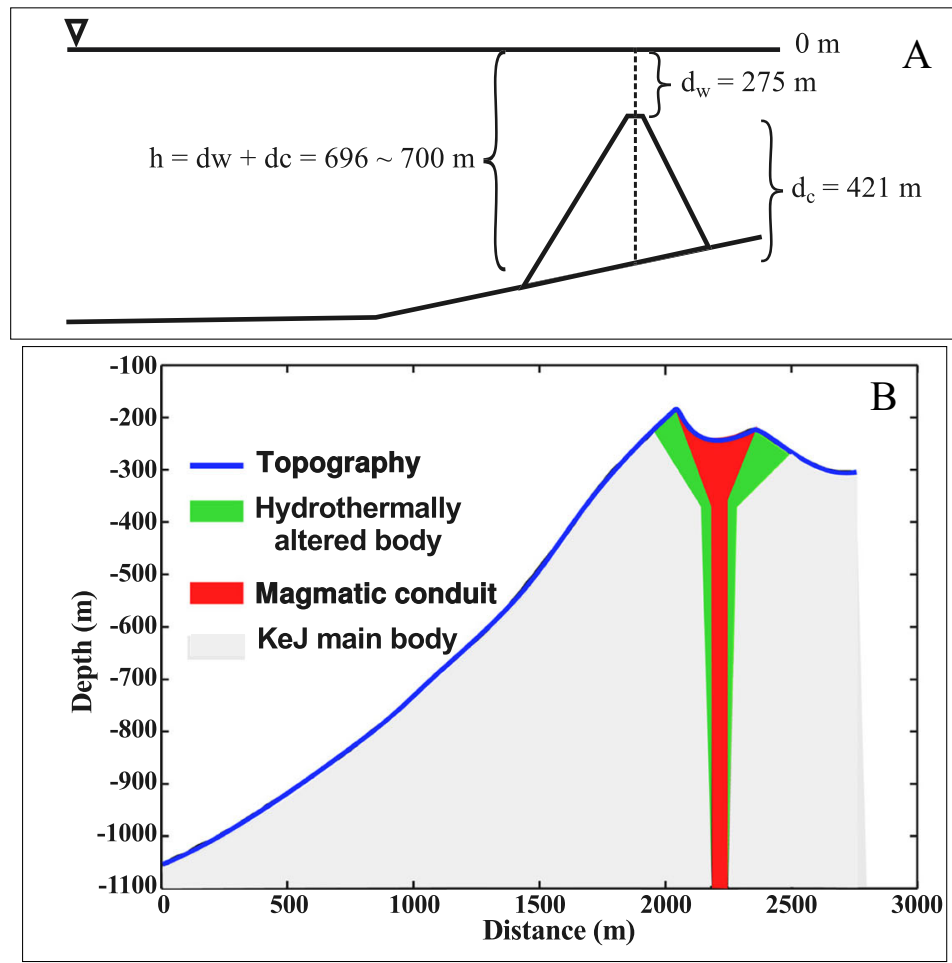

A

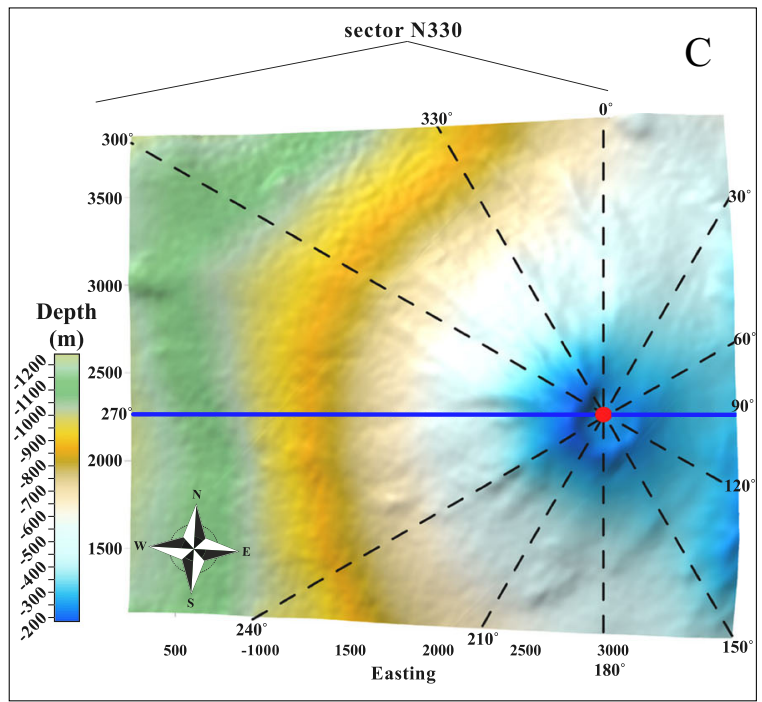

Fig. 3 Models: a model to estimate the pore fluid pressure $\left(P_{\mathrm{p}}\right)$, equivalent here to the hydrostatic pressure at the base of the current $\mathrm{KeJ}$ edifice; $\mathbf{b}$ three layers internal structure of KeJ edifice (after Borselli et al.
2011); 12 sectors used for the slope stability analysis with half sector of constant angular step of $30^{\circ}$ after Borselli et al. (2011) 
parameters. The combination of both produces a slope geomechanical model that is tested by calculating the ratio of the resisting forces over the driving forces, i.e., the stability factor $(\mathrm{Fs})$.

Edifice parameterization requires an internal structure model. We applied the three strata model used by Borselli et al. (2011) (Fig. 3b). In the case of KeJ, we assume that the main body is characterized by sample NA039-056-02 (stratum 1) and that a hydrothermally altered body (stratum 2) envelops a magma conduit characterized by sample NA039-013-03 (stratum 3).

Similar to Borselli et al. (2011), we applied Janbu's rigorous method (Janbu 1973) and generalized computational and searching strategies to find the sliding surface with the minimum stability factor (Fs) (Siegel et al. 1981; Chen 1992; Zhu et al. 2003, 2005). We performed the analysis using the same DTM as used for the deficit/surplus analysis. Our DTM analysis divided the KeJ edifice into 12 sectors drawn at constant $60^{\circ}$ angular steps, in clockwise order and centered on the summit of the volcanic structure, with half sector retrieved from the method of Borselli et al. (2011). Figure 3c displays the main directions, i.e., the median axis departing from the summit of each slice. For each sector, assuming the internal structure presented in Fig. 3b, the Slope Stability Analysis Program (SSAP2010; http://www.ssap.eu/) software looked for the critical sliding surface, characterized by the minimum stability factor Fs, in a set of randomly generated samples containing 10,000 potential sliding surfaces. Our simulations of Fs were carried using the 32-bit version 4.7.6 of SSAP2010 (32 bit) using WINE ${ }^{\mathrm{HQ}}$ emulator running on a 64-bit DEBIAN Jessie 8 distribution installed on a PC with Intel ${ }^{\circledR}$ Xeon ${ }^{\mathrm{TM}}$ Quad Core processor and 12 Go DDR3 ram capacity.

For each of the 12 sectors, the input data are the reconstructed slope profile of the median axis of the sector and the height geomechanical parameterization. The default geomechanical parameterization, i.e., scenario 1 (Table 2), was carried out based on the Geological Strength Index (GSI) method (Hoek and Brown 1997; Hoek et al. 1998, 2002). The GSI method provides an estimate for the reduction in strength for various geological conditions identified by field observations and it retrieves the local equivalent shear strength Mohr-Coulomb parameters for fractured rock masses. Full implementation of the GSI method was performed for stratum 2 , based on the highly altered basaltic andesite samples collected within the inner crater during the NA039 cruise. The assumed low value of UCS is justified by the very weak cohesion of these altered rock based on the "Field estimates of the uniaxial compressive strength of intact rock pieces" (see Table 2 from Hoek et al. 1998). Indeed, laboratory measurements could not be made on this material due to its extreme fragility. We used a partial GSI method for strata 1 and 3 since their UCS and dry and saturated weights were available from the laboratory measurements (Table 1). For all scenarios (Table 3), we selected the maximum value of disturbance factor ( $D$; Hoek et al. 2002), i.e., 1. By doing so, we consider a high level of disturbance for the rock bodies within the KeJ edifice. The first six scenarios were performed taking the hydrostatic pressure $\left(P_{\text {eff }}=7 \mathrm{MPa}\right)$ into account. Scenarios 2-3-4 considered a decrease in UCS of $50 \%$ for one stratum at a time, whereas scenario 5 considered a UCS decrease of $50 \%$ for all three strata simultaneously. A pseudostatic method was used in scenario 6 to test the influence of an earthquake of magnitude $M_{\mathrm{w}}=7$ (the magnitude of the 1844 St-Vincent earthquake event; Grases 1990) with the KeJ edifice located at a distance of $50 \mathrm{~km}$ from the hypocenter. To do so, we calculated the horizontal and vertical seismic coefficients $K_{\mathrm{h}}$ and $K_{\mathrm{v}}$ from the peak ground acceleration formula proposed for subduction zone by Salazar (2004): $K_{\mathrm{h}}$ and $K_{\mathrm{v}}$ were calculated as $0.0754 \mathrm{~g}$ and $0.0377 \mathrm{~g}$, respectively. Scenarios $7-8$ are similar to scenarios 5-6 except that they were performed using null hydrostatic pressure and only for sector $\mathrm{N} 270$ of the edifice.

Table 2 Default geomechanical parameterization (scenario 1) using the Geological Strength Index (GSI) method (Hoek and Brown 1997; Hoek et al. 1998, 2002). Scenario tested with LEM modeling performed with the 4.7.6 64-bit version of the Slope Stability Analysis Program, SSAP (see Borselli et al. 2011; http://www.ssap.eu/)

\begin{tabular}{|c|c|c|c|c|c|c|c|}
\hline Stratum & $\begin{array}{l}\text { Rock } \\
\text { description }\end{array}$ & $\begin{array}{l}\text { Dry unit } \\
\text { weight } \\
\left(\mathrm{kN} / \mathrm{m}^{3}\right)\end{array}$ & $\begin{array}{l}\text { Saturated } \\
\text { unit weight } \\
\left(\mathrm{kN} / \mathrm{m}^{3}\right)\end{array}$ & $\begin{array}{l}\text { Uniaxial compressive } \\
\text { strength (MPa) }\end{array}$ & $\begin{array}{l}\text { Geological strength index } \\
\text { (nondimensional) }\end{array}$ & $\begin{array}{l}\text { Lithological } \\
\left(m_{\mathrm{i}}\right) \text { index } \\
\text { (nondimensional) }\end{array}$ & $\begin{array}{l}\text { Disturbance } \\
\text { factor }(D) \\
\text { (nondimensional) }\end{array}$ \\
\hline 1 & $\begin{array}{l}\text { Gray plagioclase-phyric } \\
\text { basaltic andesite }\end{array}$ & 23 & 24 & 55 & $55^{\mathrm{a}}$ & $20^{\mathrm{a}}$ & $1^{\mathrm{a}}$ \\
\hline 2 & $\begin{array}{l}\text { Highly altered } \\
\text { basaltic andesite }\end{array}$ & 22.5 & 23.5 & $5^{\mathrm{a}}$ & $5^{\mathrm{a}}$ & $15^{\mathrm{a}}$ & $1^{\mathrm{a}}$ \\
\hline 3 & $\begin{array}{l}\text { Black } \\
\text { plagioclase-phyric } \\
\text { basaltic andesite }\end{array}$ & 23 & 24 & 96 & $60^{\mathrm{a}}$ & $20^{\mathrm{a}}$ & $1^{\mathrm{a}}$ \\
\hline
\end{tabular}

${ }^{\mathrm{a}}$ Denotes the values that are assumed 
Table 3 Scenarios 2-3-4-5-6$7-8$ based on the default scenario (i.e., scenario 1). Scenario tested with LEM modeling performed with the 4.7.6 64-bit version of the Slope Stability Analysis Program, SSAP (see Borselli et al. 2011; http://www.ssap.eu/)

\begin{tabular}{lll}
\hline Scenario number & Scenario description & Hydrostatic pressure (MPa) \\
\hline 1 & Default parameters & 7 \\
2 & UCS decreased by $50 \%$ for strata 1 & 7 \\
3 & UCS decreased by $50 \%$ for strata 2 & 7 \\
4 & UCS decreased by $50 \%$ for strata 3 & 7 \\
5 & UCS decreased by $50 \%$ for all strata & 7 \\
6 & Scenario 5 with $K_{\mathrm{h}}=0.0754 \mathrm{~g}$ and $K_{\mathrm{v}}=0.0377 \mathrm{~g}$ & 7 \\
7 (sector N270 only) & Geomechanical models of scenarios 5 and 6 & 0 \\
8 (sector N270 only) & Scenario 5 with $K_{\mathrm{h}}=0.0754 \mathrm{~g}$ and $K_{\mathrm{v}}=0.0377 \mathrm{~g}$ & 0 \\
\hline
\end{tabular}

\section{Results}

\section{Rock mechanics}

The fresh basaltic andesite (NA039-013) contained porosities between 0.13 and 0.15 , while the porosity of the basaltic andesite containing bio-encrustation and a manganese crust (NA039-056) was 0.12 (Table 1). We find that the P-wave velocity and permeability of NA039-013 was higher than that for NA039-056 (Table 1). Figure 4a displays the stress-strain curves for the UCS tests (NA039-013-03; NA039-013-04; NA039-056-02; $P_{\text {eff }}=0 \mathrm{MPa}$ ) and the triaxial test (NA039-
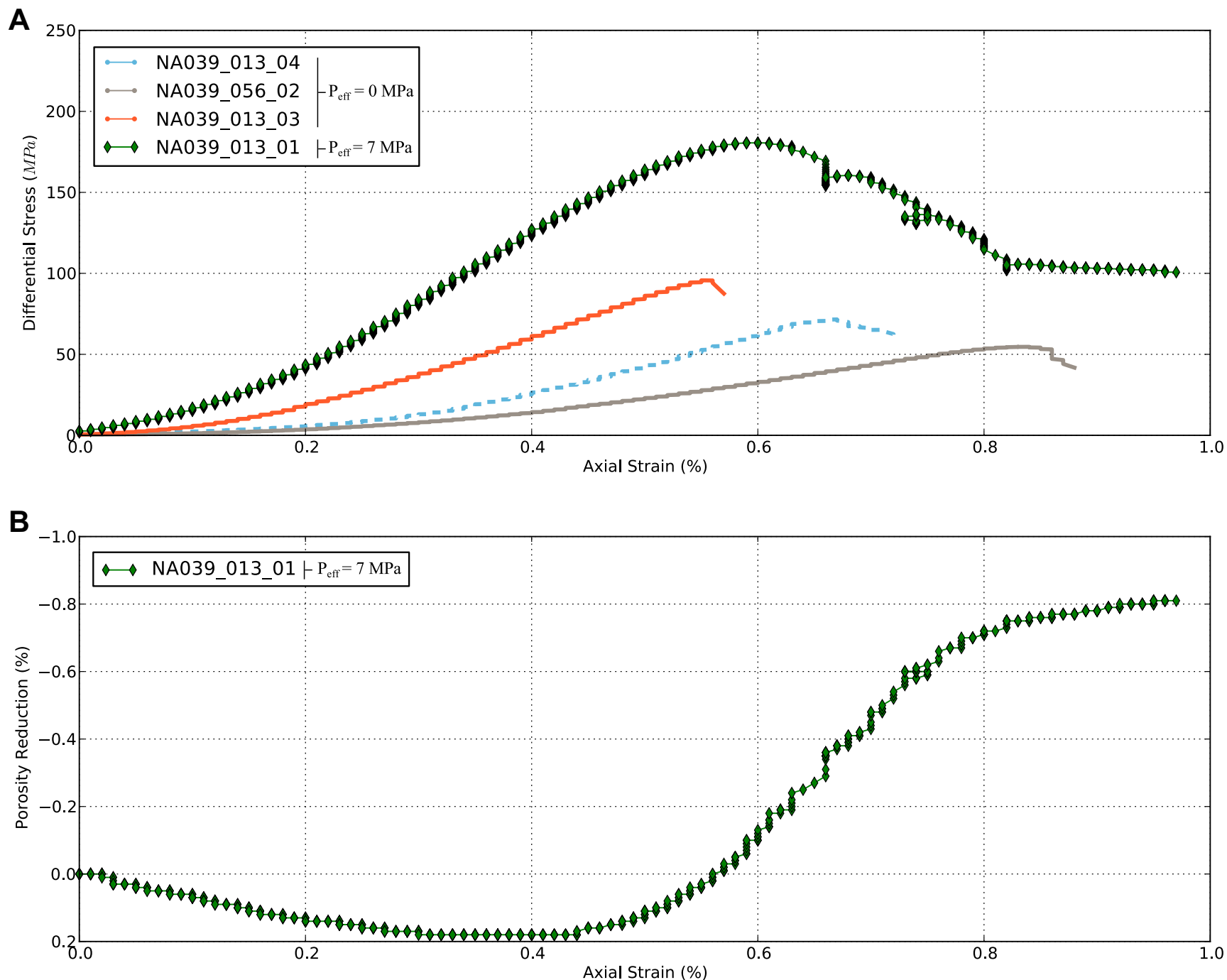

Fig. 4 Rock deformation experiments. a Stress-strain curves for deformation experiments performed at $P_{\text {eff }}=0 \mathrm{MPa}\left(\mathrm{UCS}\right.$ tests) and $P_{\text {eff }}=7 \mathrm{MPa}$ (triaxial test). b Porosity reduction (\%) as a function of axial strain (\%) for the triaxial test shown in a 
13-01; $\left.P_{\text {eff }}=7 \mathrm{MPa}\right)$. The UCS tests and triaxial test curves show brittle (dilatant) behavior characterized by strain softening and significant stress drops (Fig. 4). Following failure, all samples contained thoroughgoing fractures. Figure $4 \mathrm{~b}$ shows the sample porosity change during the triaxial experiment. The data of Fig. $4 \mathrm{~b}$ show that the sample first compacted (porosity decrease) up to an axial strain of ca. $0.4 \%$. Such compaction is commonly attributed to the closure of microcracks aligned subperpendicular to the direction of axial loading. The porosity of the sample started to increase as it was strained beyond $0.4 \%$, the result of the nucleation and growth of microcracks. Eventually, the rock reached a peak stress (Fig. 4a). Strain softening (stress drop) occurred following the peaks stress, during which a shear fracture formed in the sample. The shape of the triaxial curve is qualitatively similar to the uniaxial stress-strain curves (Fig. 4a).

We note that uniaxial compressive strength is higher for samples retrieved from the fresh lava block sourced from a columnarjointed lava dome (95.68 and 71.56 MPa for NA039-013-03 and NA039-04, respectively) than for the lava block with bioencrustation and manganese coating (54.63 MPa for NA039056-02) collected on the headwall area of the horseshoe-shaped structure (Table 1).

\section{Deficit/surplus of mass/volume analysis}

Subtraction of a DTM of the current KeJ edifice (10 m lateral resolution; Fig. 5a) with a DTM of a volcanoid (10 m lateral resolution; Fig. 5b) is presented as Fig. 5c. It reveals the presence of a significant area of deficit of mass/volume affecting the SW to NNE portion of the current KeJ edifice. The volume of deficit of mass/volume is estimated to be $0.0488 \mathrm{~km}^{3}$ with ca. $94 \%\left(0.0461 \mathrm{~km}^{3}\right)$ of this total volume focused on the sector SW-NW and ca. $6 \%$ (ca. $0.0027 \mathrm{~km}$ ) on the sector N-
NE. There is a surplus of mass/deficit with a volume estimated to be $0.0076 \mathrm{~km}^{3}$ on the upper SW sector of the crater (Fig. 5c).

\section{KeJ slope stability}

Slope stability analysis results for scenarios 1 to 6 are presented in Fig. 6. All global Fs retrieved are greater than 1. The area comprising sectors $\mathrm{N} 210$ to N0, i.e., SW to N, is associated with the lowest retrieved Fs. Within this area, sector N270 holds the lowest Fs values for each scenario (Fig. 6). Conversely, sectors NE to SE, i.e., N30 and N120, respectively, hold the highest values of global Fs.

Figure 7 shows maps of the spatial distribution of local Fs as well as the critical sliding surface associated with the minimum global Fs retrieved for each of the eight tested scenarios for the most unstable sector of the volcano (sector N270). The maps were produced using the quasiFEM algorithm which relies on a Gaussian integration and nonparametric geostatistic method to display the local Fs values calculated during the simulation using a finite element method display (Borselli 2013, 2016). The two lowest values of global Fs, Fs = 1.9097 and $\mathrm{Fs}=1.9068$, are obtained for scenarios 6 and 8, respectively, i.e., pseudostatic conditions. The lowest global Fs value is when hydrostatic pressure is zero. The highest value of global Fs, Fs $=2.9317$, is obtained for scenario 3 (a decrease of $50 \%$ of UCS value for stratum 2). The maps showing the spatial distribution of local Fs for scenarios 13-4 display a similar distribution, as well as similar shape for the critical sliding surface. For these scenarios, low values of local Fs concentrate in the near-surface deposits on the lower flank of the edifice. A decrease in the UCS value of stratum 1 by $50 \%$ (scenarios 2-5-6-7-8) generates of a second shallow zone of low local Fs values located directly beneath the crater
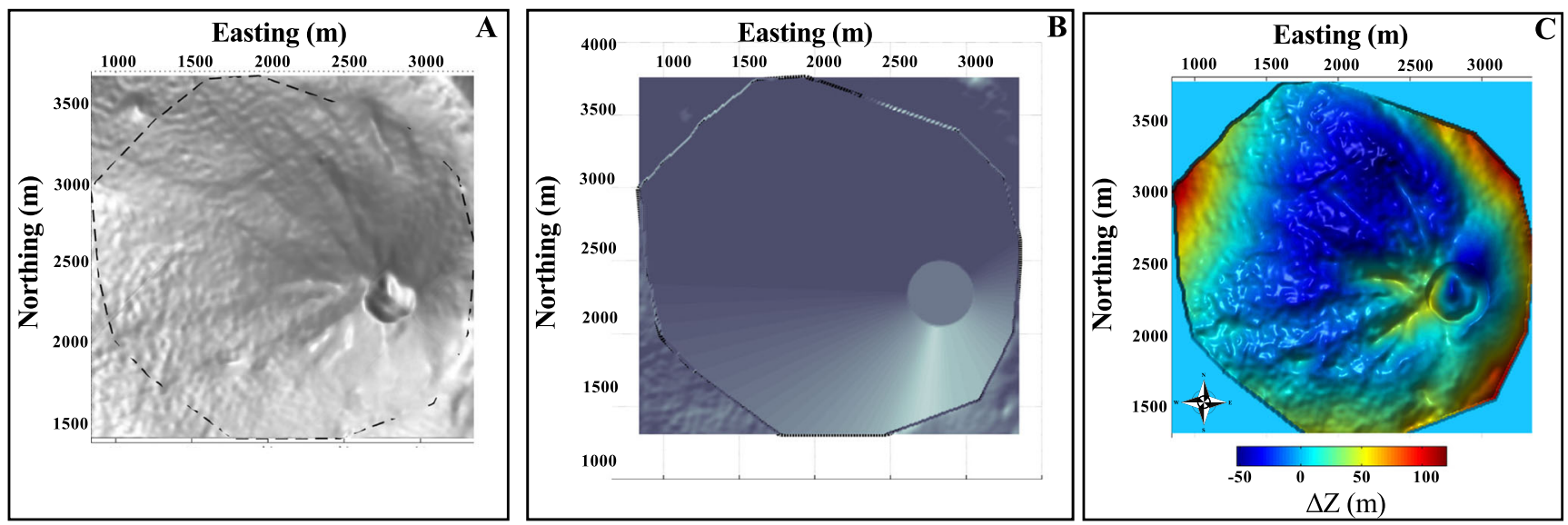

Fig. 5 VOLCANOFIT 2.0 input files (a, b) and output file (c). a Tenmeter lateral resolution digital elevation model of KeJ derived from March 2003 RB03-03 NOAA cruise at KeJ-black dashed line represents the limit of the base of KeJ edifice used to perform morphological analysis; b $10 \mathrm{~m}$ lateral resolution digital elevation model of a truncated conical 3D surface (volcanoid); c plot of deficit (negative values) or surplus (positive values) of mass/volume calculated 
Fig. 6 Global stability factor, Fs, as a function of the azimuth of volcano section. Values of Fs retrieved using Janbu's rigorous method (Janbu 1973) performed with the Slope Stability Program (SSAP) (Borselli et al. 2011). The pale gray area emphasizes the most unstable area of the current KeJ edifice, i.e., the area with minimum global Fs

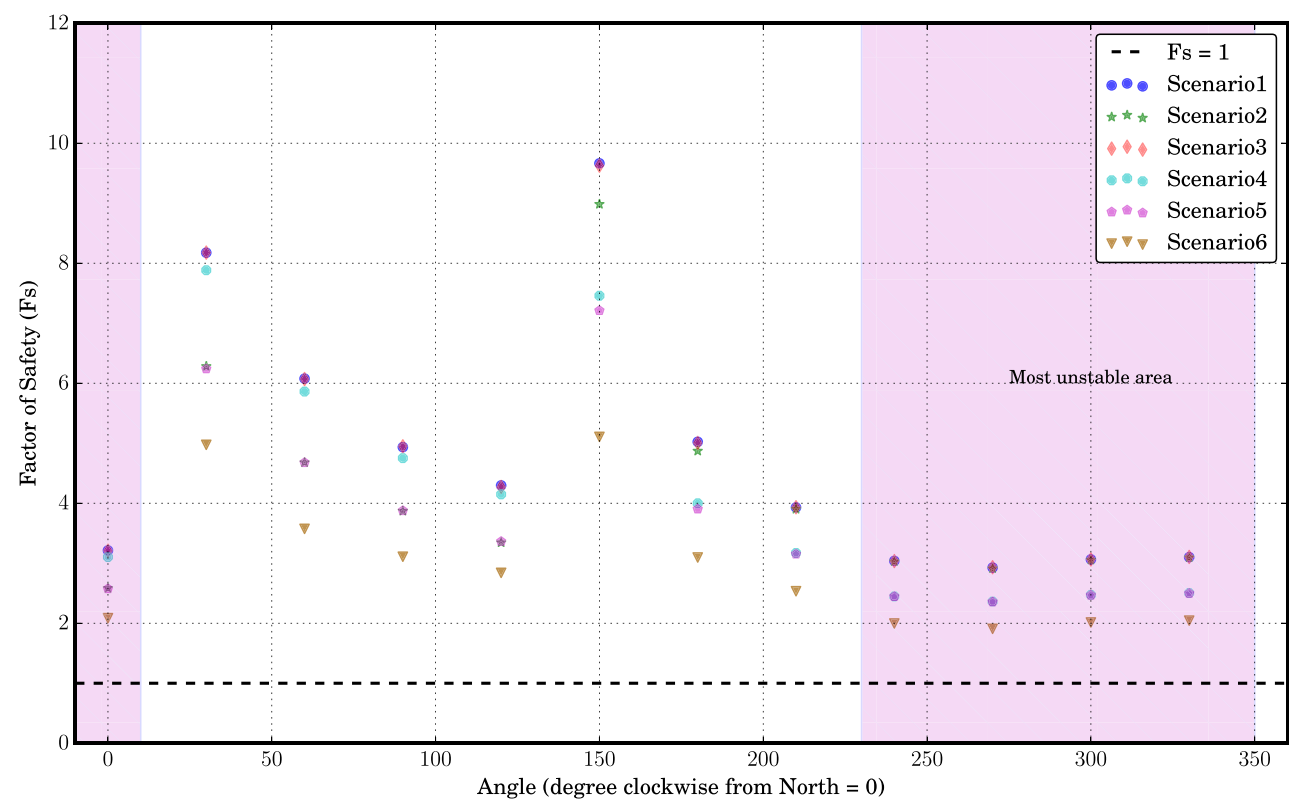

in the upper part of the edifice. For the same geomechanical configuration (scenario 5 versus 6 , and 7 versus 8 ), the pseudostatic condition (scenarios 6 and 8) generates a larger shallow upper zone of low local Fs compared to the static condition (scenarios 5 and 7).

\section{Discussion and conclusions}

We report the first rock physical property measurements for lava samples collected from KeJ submarine volcano. More realistic geomechanical models were developed using these laboratory data compared to previously published models of Dondin (pers. comm). As a consequence, the geomechanical models presented herein allow us to determine more accurate values of the stability factor (Fs) from slope stability analysis using Janbu's (1973) rigorous method as a LEM.

The rock samples collected from KeJ fail in a brittle manner at both $P_{\text {eff }}=0 \mathrm{MPa}$ (UCS test; i.e., the effective pressure within the crater) and $P_{\text {eff }}=7 \mathrm{MPa}$ (triaxial test; i.e., the effective pressure at the base of the edifice). Brittle failure at pressure equivalent to those at $(\leq 1 \mathrm{~km})$ has been observed in deformation experiments performed on porous andesite lava blocks collected from Volcán de Colima (Heap et al. 2015a). We highlight that, despite its higher porosity, the fresh lava sample (NA039-013) was stronger than the andesite basalt sample containing bio-encrustation and manganese coating (NA039-056). We conclude therefore that bio-encrustation and manganese coating may have played an important role in weakening lava sample NA039-056. Alteration has been previously shown to weaken volcanic rocks (Pola et al. 2014; Wyering et al. 2014; Heap et al. 2015b). Permeability measurements show that permeability increases as porosity increases, in accordance with other measurements on basaltic andesites and andesites (Farquharson et al. 2015; Kushnir et al. 2016; Heap and Kennedy 2016).

Our laboratory data support an improved understanding of eruptive behavior at KeJ. Brittle (dilatant) deformation triggers permeability increases for volcanic rock (Nara et al. 2011; Heap et al. 2015a; Heap and Kennedy 2016; Farquharson et al. 2016b) that can enhance the outgassing of the nearby magma-filled conduit therefore promoting effusive, rather than explosive, behavior (as discussed by many authors, e.g., Eichelberger et al. 1986; Sparks 1997; Melnik et al. 2005). KeJ is known for producing both effusive and explosive eruptions and these contrasting styles are thought to be related to the rate and extent of eruptive outgassing ( $\leq 5 \mathrm{wt} \%$ juvenile $\mathrm{H}_{2} \mathrm{O}$ ) and potential magma interaction with external water (Devine and Sigurdsson 1995). At KeJ, we propose that the effusive eruptive style is mainly the result of efficient outgassing, the consequence of brittle deformation increasing the permeability of the host rock. Outgassing can be seen at, for example, Champagne Vent $\left(-61^{\circ} .6379 \mathrm{~W}, 12^{\circ} .30131 \mathrm{~N}\right.$; Fig. 8). Efficient outgassing likely permitted construction of the lava dome that formed in the mid-1980s (i.e., effusive behavior) that was later destroyed during the 1988 eruption (Shepherd 1988; Sigurdsson 1989). By contrast, explosive behavior at KeJ may be the result of (i) rapid magma ascent toward the surface that prevents efficient outgassing to occur through the fracture networks and (ii) the pressurization of exsolved gases due to the presence of a low-permeability lava dome capping the crater.

We interpret the deficit of mass/volume areas SW-NW as the result of erosion associated with volcanic mass flows (e.g., pyroclastic flows, dome collapse) that occurred during past explosive eruptions at the volcano. This result is consistent with the area of 

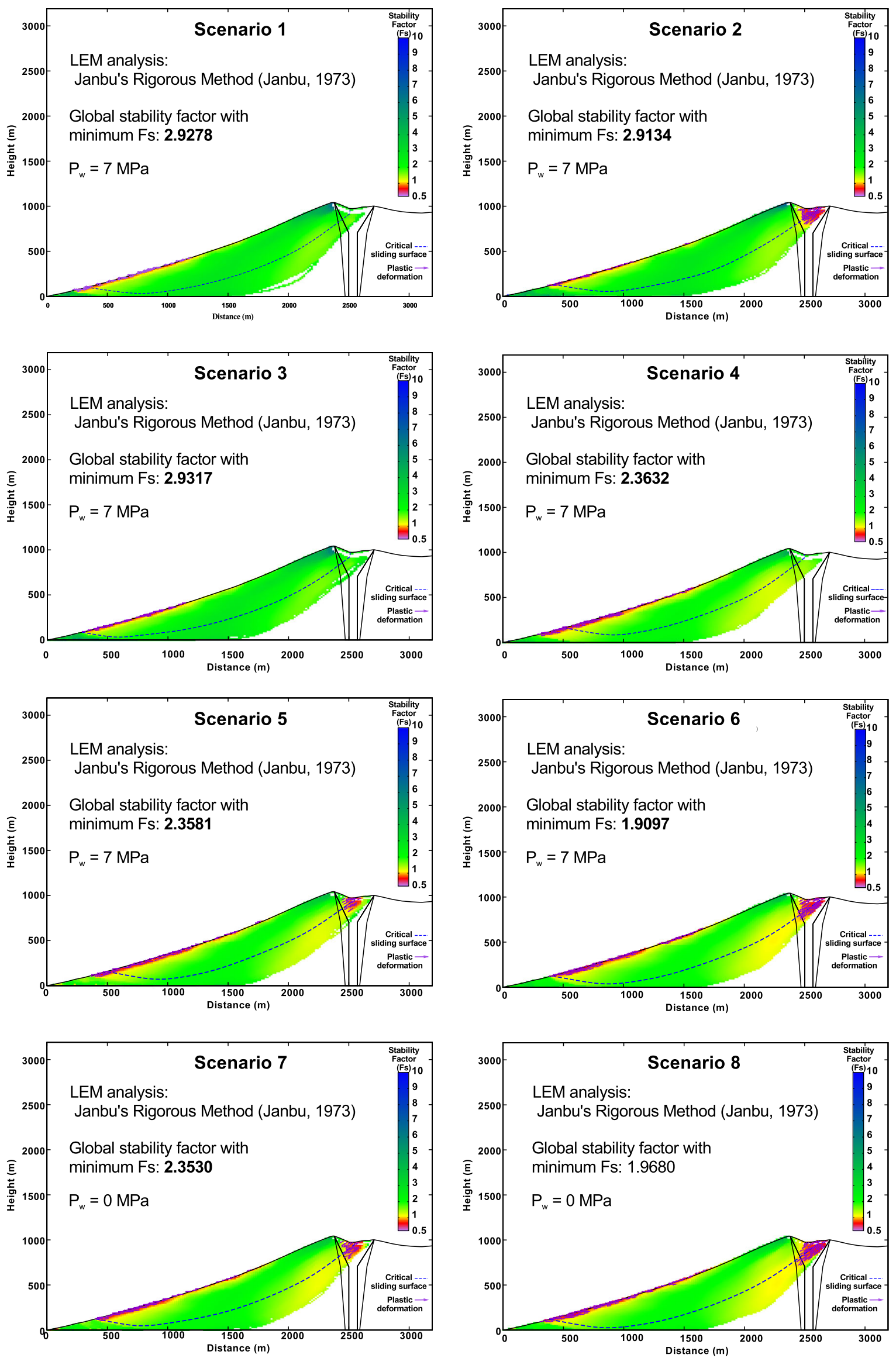
Fig. 7 Cross-sectional diagrams showing local factor of stability (Fs) against the critical sliding surface associated with minimum global Fs for scenarios 1-2-3-4-5-6-7-8 at sector N270 (west). Cross sections produced with q-FEM algorithm (Borselli 2013, 2016) available in SSAP2010 4.7.6. 32-bit version. $\mathrm{P}_{\mathrm{w}}$ is the hydrostatic pressure.

lowest Fs value retrieved from the LEM analysis. Similar results were obtained by Dondin (pers. comm) who applied the same relative slope stability analysis at KeJ but with literature-based geomechanical models to perform the LEM analysis. As for Volcán de Colima, the observed SW flank deficit seems to be correlated with the major relative instability in the same quadrant (Borselli et al. 2011). If the style of eruptive activity remains effusive, with no major change in the edifice (formation of a cryptodome), the erosion of the SW-NW sector due to mass flow may lead to the collapse of this sector. We interpret the N-NE sector eroded area as the consequence of a dome collapse event that occurred during the 1988 explosive eruption (Shepherd 1988; Sigurdsson 1989; Lindsay et al. 2005). This event contributed to dismantling of the lava dome that capped the crater at the end of the 1977 eruption (McClelland et al. 1989). We propose that the area surplus of mass/volume on the SW sector of the crater is the consequence of diking.

In the current underwater condition (i.e., considering $P_{\text {eff }}=$ $7 \mathrm{MPa}$ ), the KeJ edifice is stable because global Fs values are greater than unity in all of the tested scenarios. Sectors N210 to
N330 (SW-NW) are the least stable sectors of the edifice, with the most unstable sector striking toward N270 (west). Conversely, the two most stable sectors extend from the summit to the NE and SE, respectively. The analysis of the spatial distribution of local Fs for the western sector (Fig. 7) allows us to identify the weakest zones (i.e., local Fs $<1$ ) within each of the 12 sectors analyzed. The lowest local Fs values are associated with the generation of inelastic (i.e., plastic) deformation associated with cracking and sliding motion relative to these cracks, as highlighted by the purple arrows in Fig. 7. Under current geomechanical conditions simulated by scenario 1 , our results indicate that the weakest zone(s) are concentrated in the nearsurface deposits on the lower flank of the volcano. If there is a failure of this zone, it is likely that no hazardous tsunami would be triggered.

The present study does not test the effect of internal fluid pressurization on the stability of the edifice in its present state. For example, if we speculate that a cryptodome formed at KeJ edifice, the stability of the SW-N sectors and in particular the SW-NW sector would be reduced significantly, making it prone to collapse. In such a scenario, a volume of at least $0.7 \mathrm{~km}^{3}$ could be mobilized; such a mobilized volume failing as a single block would trigger a tsunami with hazardous surface elevations that would lead to hazardous run-ups in the near-field domain (Fig. 9) extending to NNW coast of Grenada and the southernmost Grenadines islands (Ronde and Caille). Furthermore, Carey

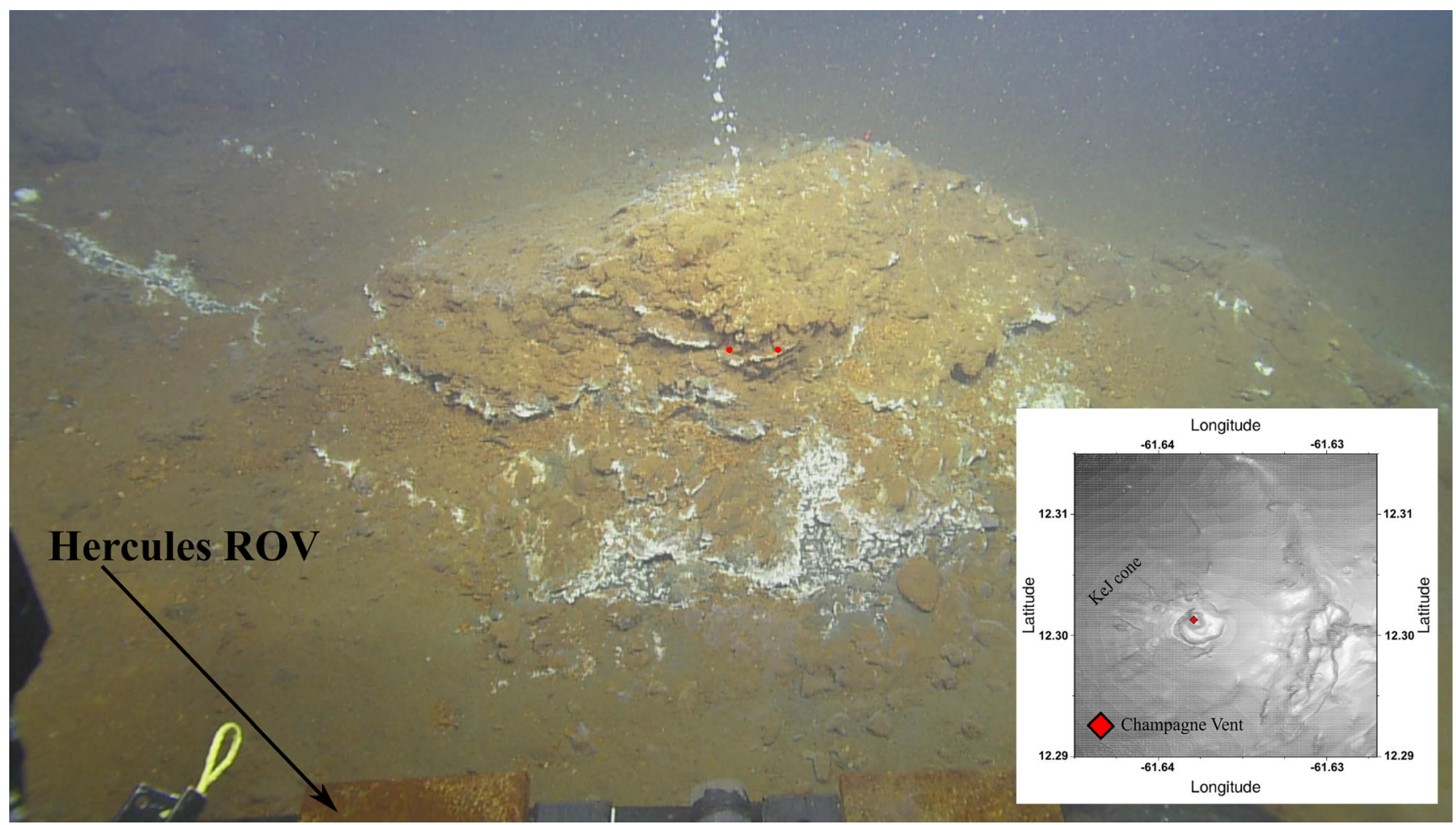

Fig. 8 Champagne Vent hydrothermal mound located in the inner crater of KeJ $\left(12^{\circ} .30131 \mathrm{~N} ; 61^{\circ} .6379 \mathrm{~W}\right)$. Vent outgasses translucent bubblesbarely visible on the picture - and whitish bubbles of centimetric size.
Signature of outgassed volatiles is $93-96 \% \mathrm{CO}_{2}$ with trace amounts of methane and hydrogen (Carey et al. 2016). The red laser dots provide the scaling and are $10 \mathrm{~cm}$ apart 
Fig. 9 Tsunami hazards assessment at KeJ for a sector collapse scenario at KeJ involving $0.73 \mathrm{~km}^{3}$ collapsing as a single pulse from the sector N270 (western sector). Inset: maximum surface elevations retrieved from tsunami propagation in the nearfield domain (red square) during the $2218 \mathrm{~s}$ of a simulation performed using FUNWAVE TVD (Shi et al. 2012). White areas represent coastal areas associated with run-ups generation (not investigated here). Simulation was carried using the 2014 version of General Bathymetric Chart of the Oceans (GEBCO) 30 arc sec. Background map displays the geographical location of Grenada and Carriacou (adapted from Lindsay et al. 2005). We also show the locations of the southernmost Grenadines islands

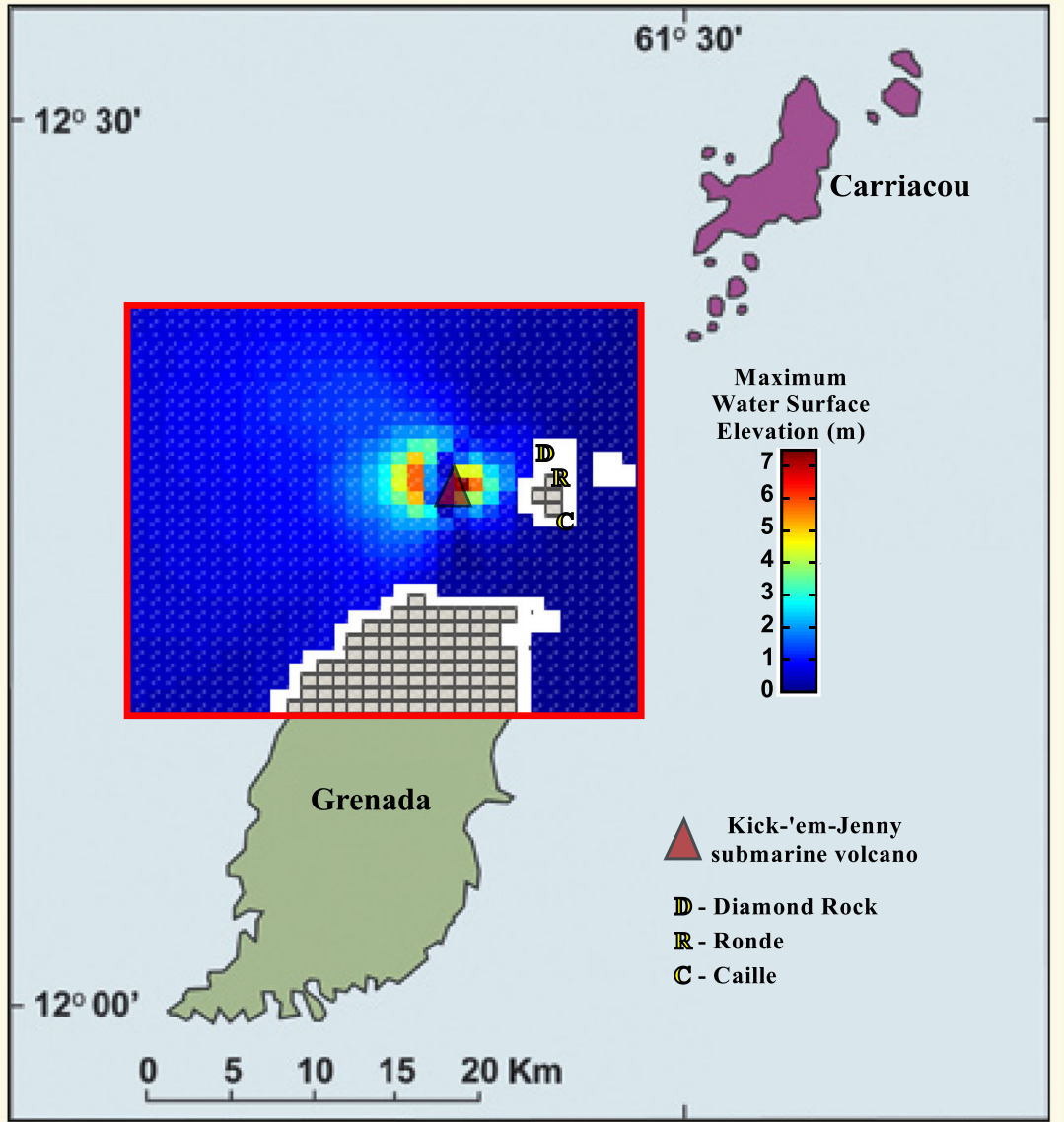

et al. (2016) revealed the existence of an active shallow hydrothermal system directly beneath the crater. These authors proposed that such a system is likely ephemeral because of the decadal eruptive pattern of KeJ. Since fluid pressurization due to formation of a hydrothermal system (or a cryptodome) is one of the major factors promoting the instability of volcanic edifices, the quantification of internal fluid pressurization related to the shallow hydrothermal system at $\mathrm{KeJ}$ is of great interest to assess its effects on the stability of the volcano where its shallow sector creates slopes greater than $30^{\circ}$. We highlight fluid pressurization at $\mathrm{KeJ}$ as an important topic for future investigation.

Finally, to our knowledge, these new results concerning the slope stability at KeJ are the first to be published for a submarine volcano. This work can be seen as a continuation of the seminal work by Iverson (1995) dealing with the problem of slope stability of Hawaiian volcanoes. We hope that the present study will stimulate new interest in the slope stability of active seamounts in other areas worldwide.

Acknowledgments We would first like to thank Bettina Scheu (LMU, Munich) for stimulating collaboration. We would also like to thank Robert Ballard and Katherine Croff Bell of the Ocean Exploration Trust for providing the opportunity to collect the rock samples during the NA039 $E / V$ Nautilus cruise. We thank Sarah Fuller, the data manager for the NA039 $E / V$ Nautilus cruise, for describing the rock samples.
Finally, we thank the National Science Foundation grant OCE-0956368 for providing the support for the curation and distribution of the geological samples at the University of Rhode Island. Michael Heap acknowledges funding from an Initiative d'Excellence (IDEX) "Attractivité" grant (VOLPERM), funded by the University of Strasbourg. We also thank Thierry Reuschlé, Jamie Farquharson, and Alex Kushnir for experimental support at Université de Strasbourg. The constructive comments of Lorenzo Borselli, one anonymous reviewer, and Executive Editor James White helped improve and clarify this manuscript. We also thank Associate Editor Josef Dufek for his handling of the peer-review process.

Open Access This article is distributed under the terms of the Creative Commons Attribution 4.0 International License (http:// creativecommons.org/licenses/by/4.0/), which permits unrestricted use, distribution, and reproduction in any medium, provided you give appropriate credit to the original author(s) and the source, provide a link to the Creative Commons license, and indicate if changes were made.

\section{References}

Apuani T, Corazzato C (2009) Numerical model of the Stromboli volcano (Italy) including the effect of magma pressure in the dyke system. Rock Mechanics and Rock Engineering 42:53-72

Apuani T, Corazzato C (2010) Etna flank dynamics: a sensitivity analysis by numerical modeling. In: ISRM International Workshop on Rock Mechanics and Geoengineering in Volcanic Environments. International Society for Rock Mechanics, Puerto de la Cruz 
Apuani T, Corazzato C, Cancelli A, Tibaldi A (2005) Stability of a collapsing volcano (Stromboli, Italy): limit equilibrium analysis and numerical modeling. J Volcanol Geotherm Res 144:191-210

Auker MR, Sparks RSJ, Siebert L, Crosweller HS, Ewert J (2012) A statistical analysis of the global historical volcanic fatalities record. JAppl Volcanol 2:2. doi:10.1186/2191-5040-2-2

Borselli L (2013) Advanced 2D slope stability analysis by LEM by SSAP software: a full freeware tool for teaching and scientific community. In: Sassa K, He B, McSaveney M, Nagai O (eds) ICL landslide teaching tools, International Consortium on Landslides (ICL), $\mathrm{p}$ 428. ISBN: 978-4-9903382-2-0

Borselli L (2016) SSAP 4.7.2 - slope stability analysis program. Manuale di Riferimento. del Codice SSAP Versione 4.7.2 http://www.ssap. eu/ (last accessed 15 Sept 2016). doi:10.13140/RG

Borselli L, Capra L, Sarocchi D, De la Cruz-Reyna S (2011) Flank collapse scenarios at Volcán de Colima, Mexico: a relative instability analysis. J Volcanol Geotherm Res 208:51-65

Boudon G, Semet MP, Vincent PM (1984) Flank failure-directed blast eruption at Soufrière, Guadeloupe, French West Indies: a 3,000-yrold Mt. St. Helens? Geology 12:350-353

Boudon G, Semet MP, Vincent PM (1987) Magma and hydrothermally driven sector collapses: the 3100 and 11500 Y. B.P. eruptions of La Grande Découverte volcano, Guadeloupe, French West Indies. J Volcanol Geotherm Res 33:317-323

Boudon G, Komorowski JC, Semet MP, Le Friant A, Deplus C (1999) Frequent volcanic flank collapses in the lesser Antilles Arc: origin and hazards. (abstract), Eos Trans AGU, 80(46), Fall Meet. Suppl., F1142

Boudon G, Le Friant A, Komorowski J-C, Deplus C, Semet MP (2007) Volcano flank instability in the Lesser Antilles Arc: diversity of scale, processes, and temporal recurrence. J Geophys Res 112: B08205. doi:10.1029/2006JB004674

Brunet M, Le Friant A, Boudon G, Lafuerza S, Talling P, Hornbach M, Ishizuka O, Lebas E, Guyard H and IODP Expedition 340 Science Party (2016) Composition, geometry and emplacement dynamics of a large volcanic island landslide offshore Martinique: from volcano flank-collapse to seafloor sediment failure? Geochem Geophys Geosyst. 17. doi:10.1002/2015GC006034

Carey S et al (2014) Fluid/gas venting and biological communities at Kick'em Jenny submarine volcano, Grenada (West Indies). Oceanography 27(1):38-41

Carey S, Olsen R, Bell KLC, Ballard R, Dondin F, Roman C, Smart C, Lilley M, Lupton J, Seibel B, Cornell W, Moyer C (2016) Hydrothermal venting and mineralization in the crater of Kick'em Jenny submarine volcano, Grenada (Lesser Antilles). Geochem Geophys Geosyst 17:1000-1019. doi:10.1002/2015GC006060

Chen ZY (1992) Random trials used in determining global minimum factors of safety of slopes. Can Geotech J 29:225-233

Crutchley GJ et al (2013) Insights into the emplacement dynamics of volcanic landslides from high-resolution 3D seismic data acquired offshore Montserrat, Lesser Antilles. Mar Geol 335:1-15. doi:10.1016/j.margeo.2012.10.004

Deplus C, Le Friant A, Boudon G, Komorowski J-C, Villemant B, Harford C, Ségoufin J, Cheminée JL (2001) Submarine evidence for large-scale debris avalanches in the Lesser Antilles Arc. Earth Planet Sci Lett 192:145-157

Devine JD, Sigurdsson H (1995) Petrology and eruption styles of Kick'em Jenny submarine volcano, Lesser Antilles island arc. Jour Volcanol Geotherm Res 69:35-58

Dondin F (2010) Simulations numériques et impact tsunamogène d'une déstabilisation de flanc au volcan sous-marin Kick'em Jenny, Petites Antilles. PhD thesis, Université des Antilles et de la Guyane, France. p 1-256

Dondin F, Lebrun J-F, Kelfoun K, Fournier N, Randrianasolo A (2012) Sector collapse at Kick'em Jenny Submarine Volcano (Lesser Antilles): numerical simulation and landslide behaviour. Bull Volcanol 74:597-607
Donnadieu F, Merle O, Besson JC (2001) Volcanic edifice stability during cryptodome intrusion. Bull Volcanol 63:61-72. doi:10.1007 /s004450000122

Eichelberger JC, Carrigan CR, Westrich HR, Price PH (1986) Nonexplosive silicic volcanism. Nature 323:598-602

Elsworth D, Voight B (1996) Evaluation of volcano flank instability triggered by dyke intrusion. Geol Soc Lond Spec Publ 110:45-53. doi:10.1144/GSL.SP.1996.110.01.03

Farquharson JI, Heap MJ, Varley N, Baud P, Reuschlé T (2015) Permeability and porosity relationships of edifice-forming andesites: a combined field and laboratory study. J Volcanol Geotherm Res 297:52-68

Farquharson JI, Heap MJ, Baud P, Reuschlé T, Varley N (2016a) Pore pressure embrittlement in a volcanic edifice. Bull Volcanol 78(6)

Farquharson JI, Heap MJ, Baud P (2016b) Strain-induced permeability increase in volcanic rock. Geophys Res Lett. 43. doi:10.1002/ 2016GL071540

Friant A, et al. (2015) Submarine record of volcanic island construction and collapse in the Lesser Antilles arc: first scientific drilling of submarine volcanic island landslides by IODP Expedition 340 . Geochem Geophys Geosyst 16:420-442. doi:10.1002/2014 GC005652

Fritz HM, Mohammed F, Yoo J (2009) Lituya Bay landslide impact generated mega-tsunami 50th anniversary. Pure Appl Geophys 166(1-2):153-175. doi:10.1007/s00024-008-0435-4

Fritz HM, Hillaire JV, Molière E, Wei Y, Mohammed F (2013) Twin tsunamis triggered by the 12 January 2010 Haiti earthquake. Pure Appl Geophys 170(9-10):1463-1474. doi:10.1007/s00024-012-0479-3

Grases J (1990) Terremotos Destructores del Caribe 1502-1990. Una Contribucción al Decenio Internacional para la Reducción de los Dessastres Naturales. Caracas. UNESCO - RELACIS

Harbitz CB, Løvholt F, Pedersen G, Masson DG (2006) Mechanisms of tsunami generation by submarine landslides: a short review. Nor J Geol 86:255-264

Harbitz CB, Glimsdal S, Bazin S, Zamora N, Smebye HC, Løvholt F, Bungum H, Gauer P, Kjekstad O (2012) Tsunami hazard in the Caribbean: regional exposure derived from credible worst case scenarios. Cont Shelf Res 38:1-23

Heap MJ, Kennedy BM (2016) Exploring the scale-dependent permeability of fractured andesite. Earth Planet Sci Lett. doi:10.1016/j.epsl.2016.05.004

Heap MJ, Wadsworth FB (2016) Closing an open system: pore pressure changes in permeable edifice rock at high strain rates. J Volcanol Geotherm Res. doi:10.1016/j.jvolgeores.2016.02.011

Heap MJ, Lavallée Y, Petrakova L, Baud P, Reuschlé T, Varley N, Dingwell DB (2014a) Microstructural controls on the physical and mechanical properties of edifice-forming andesites at Volcán de Colima, Mexico. J Geophys Res 119:2925-2963

Heap MJ, Baud P, Meredith PG, Vinciguerra S, Reuschlé T (2014b) The permeability and elastic moduli of tuff from Campi Flegrei, Italy: implications for ground deformation modelling. Solid Earth 5:25-44

Heap MJ, Farquharson JI, Baud P, Lavallée Y, Reuschlé T (2015a) Fracture and compaction of andesite in a volcanic edifice. Bull Volcanol 77(55):1-19

Heap MJ, Kennedy BM, Pernin N, Jacquemard L, Baud P, Farquharson IJ, Scheu B, Lavallée Y, Gilg HA, Letham-Brake M, Mayer K, Jolly AD, Reuschlé T, Dingwell DB (2015b) Mechanical behaviour and failure modes in the Whakaari (White Island volcano) hydrothermal system, New Zealand. J Volcanol Geotherm Res 295:26-42

Hoek E, Brown ET (1997) Practical estimates of rock mass strength. Int J Rock Mech Min Sci 34(8):1175-1186

Hoek E, Marinos P, Benissi M (1998) Applicability of the geological strength index (GSI) classification for very weak and sheared rock masses. The case of the Athens Schist Formation. Bull Eng Geol Env 57:151-160 
Hoek E, Carranza-Torres C, Corkum B (2002) Hoek-Brown criterion2002 edition. Proc. NARMS-TAC Conference, Toronto 1, p 267-273

Hürlimann M, Martí J, Ledesma A (2000) Mechanical relationship between catastrophic volcanic landslides and caldera collapses. Geophys Res Lett 27(16):2393-2396

Iverson R (1995) Can magma-injection and groundwater forces cause massive landslides on Hawaiian volcanoes? J Volcanol Geotherm Res 66(1995):295-308

Janbu N (1973) Slope stability computations. The Embankment Dam Engineering Casagrande Volume. Wiley, New York, p 47-86

Karstens J, Crutchley GJ, Berndt C, Talling PJ, Watt SFL, Trofimovs J, Hühnerbach V, Le Friant A, Lebas E (2013) Insights into pyroclastic flow emplacement from high-resolution 3D seismic data offshore Montserrat, Lesser Antilles. J Volcanol Geotherm Res 257:1-11

Komorowski J-C, Boudon G, Semet M, Beauducel F, Anténor-Habazac C, Bazin S, Hammouya G (2005) Guadeloupe. In: Lindsay JM et al (eds) Volcanic atlas of the Lesser Antilles. Univ. of the West Indies, Seismic Res. Unit, Trinidad, pp 65-102

Kushnir ARL, Martel C, Bourdier J-L, Heap MJ, Reuschlé T, Erdmann S, Komorowski J-C, Cholik N (2016) Probing permeability and microstructure: unravelling the role of a low-permeability dome on the explosivity of Merapi (Indonesia). J Volcanol Geotherm Res. doi:10.1016/j.jvolgeores.2016.02.012

Latchman JL, Dondin FJ-Y, Robertson REA, Lynch Ll, Stewart R, Smith P, Ramsingh C, Nath N, Ramsingh H, Ash C, Team SRC (2015) Insights on volcanic behaviour from the 2015 July 23-24 T-phase signals generated by eruptions at Kick-'em-Jenny submarine volcano, Grenada, Lesser Antilles. The American Geophysical Union, Fall Meeting, San Francisco, United States of America, 14-18 December, 2015. Oral presentation

Le Friant A, Boudon G, Komorowski J-C, Deplus C (2002) L'île de la Dominique, à l'origine des avalanches de débris les plus volumineuses de l'arc des Petites Antilles. C R Geosci 334(4): $235-243$

Le Friant A, Boudon G, Deplus C, Villemant B (2003) Large scale flank collapse events during the activity of Montagne Pelée, Martinique Lesser Antilles. J Geophys Res 108(B1):2055. doi:10.1029/2001JB001624

Le Friant A, Boudon G, Arnulf A, Robertson REA (2009) Debris avalanche deposits offshore St. Vincent (West Indies): impact of flankcollapse events on the morphological evolution of the island. J Volcanol Geotherm Res 179:1-10

Le Friant A, Harford CL, Deplus C, Boudon G, Sparks RSJ, Herd RA, Komorowski JC (2004) Geomorphological evolution of Montserrat (West Indies): importance of flank collapse and erosional processes. J Geol Soc 161(1): 147-160

Lebas E, Le Friant A, Boudon G, Watt S, Talling P, Feuillet N, Deplus C, Berndt C, Vardy M (2011) Multiple widespread landslides during the long-term evolution of a volcanic island: insights from highresolution seismic data, Montserrat Lesser Antilles. Geochem Geophys Geosyst 12:Q05006. doi:10.1029/2010GC003451

Legendre Y (2012) Reconstruction fine de l'histoire éruptive et scénarii éruptifs à la Soufrière de Guadeloupe : vers un modèle intégré de fonctionnement du volcan. PhD thesis, IPGP- Université Paris D. Diderot, France. vol. 1, p 1-426

Lindsay JM, Shepherd JB (2005) Kick'em Jenny and Ile de Caille. In: Lindsay JM et al (eds) Volcanic atlas of the Lesser Antilles. Univ. of the West Indies, Seismic Res. Unit, Trinidad, pp 105-125

Lindsay J, Shepherd JB, Wilson D (2005) Volcanic and scientific activity at Kick'em Jenny submarine volcano 2001-2002: implications for volcanic hazards in the southern Grenadines, Lesser Antilles. Nat Hazards 34:1-24

McClelland L, Simkin T, Summers M, Nielson E, Stein TC (eds) (1989) Global volcanism 1975-1985. Prentice Hall and American Geophysical Union, p 653
McFall BC, Fritz HM (2016) Physical modelling of tsunamis generated by $3 \mathrm{D}$ deformable granular landslides on planar and conical island slopes. Proc R Soc A 472(2188):20160052. doi:10.1098 /rspa.2016.0052

McGuire WJ (1996) Volcano instability: a review of contemporary themes. In: McGuire WJ, Jones AP, Neuberg J (eds) Volcano instability on the earth and other planets. Geological Society Special Publication, $\mathrm{p}$ 1-23

Melnik O, Barmin AA, Sparks RSJ (2005) Dynamics of magma flow inside volcanic conduits with bubble overpressure buildup and gas loss through permeable magma. J Volcanol Geotherm Res 143:53-68

Nara Y, Meredith PG, Yoneda T, Kaneko K (2011) Influence of macrofractures and micro-fractures on permeability and elastic wave velocities in basalt at elevated pressure. Tectonophysics 503:52-59

Nishimura Y (2008) Volcanism-induced tsunamis and tsunamiites. In: Shiki $\mathrm{T}$, et al. (eds.) Tsunamiites - features and implications. Elsevier, Amsterdam, p 319-340, doi:10.1016/B978-0-444-51552-0.00018-7

Okubo CH (2004) Rock mass strength and slope stability of the Hilina slump, Kilauea volcano, Hawaii. J Volcanol Geotherm Res 138:4376. doi:10.1016/j.jvolgeores.2004.06.006

Pola A, Crosta GB, Fusi N, Castellanza R (2014) General characterization of the mechanical behaviour of different volcanic rocks with respect to alteration. Eng Geol 169:1-13

Reid ME, Christian SB, Brien DL (2000) Gravitational stability of threedimensional stratovolcano edifices. J Geophys Res Solid Earth 105(B3):6043-6056

Reid ME, Sisson TW, Brien DL (2001) Volcano collapse promoted by hydrothermal alteration and edifice shape, Mount Rainer, Washington. Geology 79:779-782

Salazar Guerra WM (2004) Evaluation of source, path and site effects on earthquake ground motions using an inversion technique for subduction and upper-crustal earthquakes in El Salvador, Central America. Doctoral thesis, Tokyo Institute of Technology, Japan, pp 181

Shepherd J (1988) Reporting in: Kick'em Jenny Volcano. In: McClelland L, et al. (eds) Smithsonian Institution SEAN (Scientific Event Alert Network) Bulletin 13(12), pp 9-10

Shi F, Kirby JT, Harris JC, Geiman JD, Grilli ST (2012) A high-order adaptive time-stepping TVD solver for Boussinesq modeling of breaking waves and coastal inundation. Ocean Modell 43-44:3651. doi:10.1016/j.ocemod.2011.12.004

Siegel RA, Kovacs WD, Lovell CW (1981) Random surface generation in stability analysis. J Geotech Eng 107(7):996-1002

Sigurdsson H (1989) Reporting in: Kick'em Jenny Volcano. In: McClelland L, et al. (eds) Smithsonian Institution SEAN (Scientific Event Alert Network) Bulletin, vol. 14(5), p 12

Sigurdsson H, Shepherd JB (1974) Amphibole-bearing basalts, from the submarine volcano Kick'em Jenny in the Lesser Antilles arc. Bull Volcanol 28:891-910

Smith MS, Shepherd JB (1996) Tsunami waves generated by volcanic landslides: an assessment of the hazard associated with Kick'em Jenny. Geol Soc Lond Spec Publ 110(1):115-123

Sparks RSJ (1997) Causes and consequences of pressurisation in lava dome eruptions. Earth Planet Sci Lett 150:177-189

Trofimovs J et al (2013) Timing, origin and emplacement dynamics of mass flows offshore of SE Montserrat in the last $110 \mathrm{ka}$ : implications for landslide and tsunami hazards, eruption history, and volcanic island evolution. Geochem Geophys Geosyst 14:385-406. doi:10.1002/ggge.20052

van Wyk de Vries B, Delcamp A (2016). Volcanic debris avalanches. In: Davies $\mathrm{T}$ (Volume editor) Landslide hazards, risks, and disasters. Elsevier, Amsterdam, p 131-153

van Wyk de Vries B, Francis P (1997) Catastrophic collapse at stratovolcanoes induced by gradual volcano spreading. Nature 387:387-390

Voight B, Elsworth D (1997) Failure of volcano slopes. Geotechnique 47: $1-31$ 
Voight B, Janda RJ, Glicken H, Douglass PM (1983) Nature and mechanics of the Mount St Helens rockslide-avalanche of 18 May 1980. Geotechnique 33:243-273. doi:10.1680/geot.1983.33.3.243

Voight B, et al. (2002) In: Druitt TH, Kokelaar BP (eds) The eruption of Soufriere Hills Volcano, Montserrat, from 1995 to 1999. Geological Society, London. Memoirs, 21, p 363-407. 0435-4052/02/\$15 The Geological Society of London 2002

Ward SN, Day S (2001) Cumbre Vieja Volcano-potential collapse and tsunami at La Palma, Canary Islands. J Geophys Res 106(6):11, 201-11,215

Watt SFL et al (2012a) Combination of volcanic-flank and seafloor sediment failure offshore Montserrat, and their implications for tsunami generation. Earth Planet Sci Lett 319(2):228-240. doi:10.1016/j.epsl.2011.11.032
Watt SFL et al (2012b) Widespread and progressive seafloor-sediment failure following volcanic debris avalanche emplacement: landslide dynamics and timing offshore Montserrat, Lesser Antilles. Mar Geol 323:69-94. doi:10.1016/j.margeo.2012.08.002

Wyering LD et al (2014) Mechanical and physical properties of hydrothermally altered rocks, Taupo Volcanic Zone, New Zealand. J Volcanol Geotherm Res 288:76-93

Zhu DY, Lee CF, Jiang HD (2003) Generalised framework of limit equilibrium methods for slope stability analysis. Geotechnique 53(4):377-395

Zhu DY, Lee CF, Quian QH, Chen GR (2005) A concise algorithm for computing the factor of safety using the Morgenstern-Price method. Can Geotech J 42:272-278 